\title{
Pengaruh Motivasi Berprestasi Terhadap Kemampuan Pemecahan Masalah Matematika
}

\author{
*Putu Dara Mangku Rila Cahya 1, Gusti Ngurah Sastra Agustika ${ }^{2}$, Ni Wayan \\ Suniasih ${ }^{3}$
}

123Jurusan Pendidikan Guru Sekolah Dasar (PGSD), Universitas Pendidikan Ganesha, Singaraja, Indonesia

\section{A R T I C L E I N F O}

Article history:

Received 10 May 2019

Received in revised form 10 June 2019

Accepted 15 July 2019

Available online 29 August 2019

Kata Kunci:

Motivasi berprestasi

kemampuan pemecahan

masalah matematika

Keywords:

Achievement motivation,

math problem solving ability

\begin{abstract}
A B S T R A K
Penelitian ini bertujuan untuk mengetahui pengaruh motivasi berprestasi terhadap kemampuan pemecahan masalah matematika siswa kelas $\mathrm{V}$ SD. Hal ini berdasarkan hasil observasi, kemampuan pemecahan masalah masih perlu dilatih sejak dini terutama pada jenjang sekolah dasar. Penelitian ini merupakan penelitian ex post facto dengan jenis penelitian kausal. Populasi dari penelitian ini adalah seluruh siswa kelas $\mathrm{V}$ yang ada di SD yang berjumlah 830 orang. Sampel diambil dari populasi menggunakan teknik proportional random sampling. Jumlah sampel dari populasi ini adalah 243 orang siswa. Hasil yang didapat menunjukkan terdapat hubungan positif dan signifikan motivasi berprestasi dengan kemampuan pemecahan masalah matematika dengan hasil $r_{\text {hitung }}=0,354$ dan $r_{\text {tabel }} 0,126$ pada taraf signifikansi $(\alpha=$ $0,05 \mathrm{dan} \mathrm{dk}=241)$ maka diperoleh hasil $r_{\text {hitung }}=0,354>r_{\text {tabel }}=0,126$ dengan demikian ini berarti nilai $r_{\text {hitung }}$ signifikan, koefisien determinasi $\left(R^{2}\right)=0,125$. Berdasarkan hasil penelitian maka disimpulkan bahwa terdapat pengaruh motivasi berprestasi terhadap kemampuan
\end{abstract} pemecahan masalah matematika siswa kelas V SD sebesar 12,5\%. Adapun saran ditujukan bagi guru untuk lebih mengoptimalkan motivasi berprestasi agar siswa memiliki kemampuan pemecahan masalah matematika guna mencapai tujuan belajar matematika.

\begin{abstract}
A B S T R A C T
This study aimed to determine the effect of achievement motivation to the problem solving skills of mathematics students of fifth grade at SD. This research was an ex post facto research with kind of causal research. The population of this study was fifth grsde students at SD Gugus I Kuta Utara amounted to 830 students. Samples were taken from the population using proportional random sampling technique. The sample size of this population was 243 students. The result showed that a positive and significant correlation between achievement motivation with mathematical problem solving ability with rhitung $=0,354$ and rtabel 0,126 at significance level $(\alpha=0,05$ and $d k=241)$ hence obtained result rhitung $=0,354>$ rtabel $=0,126$ thus this means the value of rhitung is significant, the coefficient of determination $(R 2)=0.125$. Based on the result of the research, it can be concluded that there is influence of achievement motivation toward the problem solving ability of fifth grade students at $S D$ was $12,5 \%$. The suggestions intended for teachers to better optimize achievement motivation so that students have the ability to solve mathematical problems in order to achieve the purpose of learning mathematics.
\end{abstract}

\section{Pendahuluan}

Pendidikan merupakan suatu hal yang sangat bermanfaat bagi setiap orang disebut bermanfaat karena dengan pendidikan orang tersebut mampu mengembangkan kualitas dirinya. Pendidikan mampu menanamkan rasa tanggung jawab yang tinggi karena dengan pendidikan seseorang mampu mengambil sebuah keputusan. Selain itu pendidikan juga dapat dikatakan sebagai investasi jangka panjang yang memerlukan usaha yang keras untuk meraihnya. Memerlukan usaha yang keras karena dalam meraihnya terdapat kendala berupa masalah-masalah yang dapat menghambat seseorang dalam pendidikan. Kendala

Copyright (c) Universitas Pendidikan Ganesha. All rights reserved. 
yang berupa masalah-masalah tersebut timbul saat proses belajar, "belajar merupakan proses usaha yang dilakukan seseorang untuk memperoleh suatu perubahan tingkah laku yang baru secara menyeluruh, sebagai hasil pengalamannya sendiri dalam interaksi dengan lingkungannya" (Slameto, 2010). Menurut Winkle (2002) belajar merupakan salah satu proses mental mengarah kepada penguasaan pengetahuan, kecakapan, kebijaksanaan, atau sikap yang diperoleh, disimpan dan dilaksanakan sehingga menimbulkan tingkah laku yang progresif (Hadianti, 2018). Dengan demikian dalam proses belajar dapat timbul kendala berupa masalah-masalah yang dialami oleh siswa. Masalah yang timbul dalam belajar biasanya berkaitan dengan soal-soal latihan dan merupakan tantangan tersendiri bagi siswa karena siswa memerlukan suatu pemacu untuk menyelesaikan tantangan dari soal-soal latihan yang ada. Soal-soal latihan tersebut erat kaitannya dengan mata pelajaran matematika, karena siswa menilai bahwa dalam matematika banyak permasalahan yang timbul pada setiap materinya terlebih lagi materi yang membutuhkan pemikiran yang lebih mendalam untuk penyelesaiannya. Sesuai dengan kenyataan dilapangan siswa menilai mata pelajaran matematika merupakan salah satu mata pelajaran yang sulit dan menuntut siswa untuk terus berlatih. Dalam matematika terdapat dua jenis masalah yaitu masalah rutin dan masalah tidak rutin. Masalah rutin merupakan masalah yang biasa dihadapi oleh siswa dengan prosedur pengerjaannya sama dan hampir mirip dengan yang telah dipelajari oleh siswa, sedangkan masalah tidak rutin merupakan masalah yang tidak biasa ditemui siswa dan prosedur pengerjaannya pun memerlukan pemahaman dan pemikiran yang lebih mendalam(Roebyanto \& Harmini, 2017: Riffyanti, 2017). Pembelajaran matematika dalam KTSP yang merupakan suatu kumpulan pengetahuan yang tersusun secara sistematik (Trianto, 2010:130). Masalah tidak rutin merupakan salah satu masalah yang membuat siswa kesulitan dalam belajar matematika, terkadang siswa enggan untuk mengerjakan soal matematika karena masalahmasalah tidak rutin yang terdapat pada mata pelajaran matematika tersebut sangat rumit. Hal tersebut membuat siswa harus memiliki kemampuan pemecahan masalah guna mampu menyelesaikan masalahmasalah tidak rutin yang dituangkan ke dalam soal-soal cerita matematika.

Memiliki kemampuan pemecahan masalah matematika merupakan salah satu upaya dalam memperbaiki kualitas diri siswa dalam memecahkan masalah matematika. Kemampuan pemecahan masalah merupakan kemampuan dasar yang harus dimiliki oleh siswa. Kemampuan pemecahan masalah perlu dilatih sejak dini terutama pada jenjang sekolah dasar, hal ini bertujuan agar sejak dini siswa sekolah dasar memiliki kemampuan dan keinginan untuk mengembangkan dan mampu memahami pemecahan masalah terutama pemecahan masalah dalam bidang matematika. Hal ini sesuai dengan tujuan matematika menurut Departemen Pendidikan Nasional yang mengharapkan siswa mampu untuk memecahkan masalah, namun tujuan matematika tersebut belum sepenuhnya tercapai. Hal ini dikarenakan siswa tidak ingin memahami suatu masalah matematika dengan mengandalkan kemampuan pemecahan masalah matematika. Pemecahan masalah matematika merupakan suatu proses yang menghadapkan seseorang pada konsep, keterampilan, dan proses matematika untuk memecahkan masalah matematika. Pada jenjang sekolah dasar kemampuan pemecahan masalah matematika erat kaitannya dengan soal-soal cerita. Soal cerita dirangkai sedemikian rupa agar mampu dipahami oleh siswa. Menyelesaikan soal-soal cerita memerlukan kemampuan lebih untuk memahami permasalahan yang tertuang dalam soal. Walaupun setiap kali belajar matematika siswa telah diberikan cara-cara untuk memecahkan masalah namun tidak jarang siswa tidak dapat menyelesaikan masalah-masalah matematika dengan baik. Hal ini dikarenakan siswa sudah menganggap matematika merupakan mata pelajaran yang sangat sulit dan tidak dapat dipecahkan, selain itu dorongan dalam diri siswa untuk ingin memiliki kemampuan pemecahan masalah guna mencapai tujuan matematika masih sangat kurang. Siswa tidak memiliki dorongan dalam dirinya untuk mencapai tujuannya yaitu memecahkan masalah matematika.

Dorongan tersebut dibutuhkan agar siswa lebih tertarik untuk dapat atau mampu memecahkan masalah matematika. Dorongan tersebut merupakan dorongan kognitif. Dorongan kognitif merupakan dorongan yang akan mendorong siswa untuk memecahkan masalah karena dalam dorongan kognitif terdiri dari kebutuhan untuk mengetahui, kebutuhan untuk mengerti, dan kebutuhan untuk memecahkan masalah. Dorongan kognitif mencakup salah satu kebutuhan siswa untuk memecahkan masalah. Dorongan ini timbul dalam proses interaksi siswa dengan masalah yang sedang dihadapi, masalahmasalah yang dihadapi merupakan masalah yang berkaitan dengan soal-soal matematika sekolah dasar. Siswa dikatakan memiliki dorongan kognitif jika siswa tersebut sadar akan kebutuhannya untuk memecahkan masalah matematika. Dari hasil observasi dilapangan siswa masih belum sadar akan kebutuhannya untuk mampu memecahkan masalah matematika selain itu matematika merupakan salah satu mata pelajaran yang dijauhi oleh siswa sehingga siswa tidak memiliki dorongan pada dirinya untuk memiliki kemampuan pemecahan masalah matematika. Dorongan kognitif merupakan dasar terbentuknya dan dasar keberhasilan motivasi berprestasi, karena dengan adanya dorongan dalam diri siswa maka siswa akan mampu berusaha untuk meraih tujuan belajarnya berupa sebuah prestasimaka 
motivasi berprestasi dapat dijadikan sebagai pendorong keberhasilan siswa untuk memiliki kemampuan pemecahan masalah matematika.

Motivasi berprestasi merupakan kondisi fisiologis dan psikologis yang terdapat pada diri siswa yang mendorongnya melakukan aktifitas tertentu guna mencapai suatu tujuan tertentu (Djaali, 2012 : Emda, 2017). Dengan adanya motivasi maka siswa akan mengetahui tujuannya sendiri, motivasi juga memiliki peranan besar untuk membangkitkan semangat belajar siswa terutama dalam bidang matematika. Motivasi berprestasi dapat memberikan suatu dampak yang sangat baik bagi siswa untuk meraih prestasi dalam proses belajar. Tujuan yang ingin dicapai dalam motivasi berprestasi adalah tujuan untuk berprestasi, namun berdasarkan hasil observasi dilapangan sebagian besar siswa tidak memiliki tujuan yang mengharuskan dirinya untuk meraih prestasi sebanyak mungkin. McClelland (dalamDjaali, 2012) mengemukakan bahwa kebutuhan untuk berprestasi merupakan salah satu dari tiga kebutuhan hidup manusia selain kebutuhan untuk berafiliasi dan kebutuhan untuk memperoleh makan. Kebutuhankebutuhan yang ada akan menjadi sebuah acuan untuk mencapai sebuah tujuan .Motivasi akan muncul pada diri siswa, akan tetapi munculnya motivasi tersebut didorong juga oleh adanya suatu tujuan. Tujuan inilah yang biasanya jarang diketahui oleh siswa, dalam hal ini tujuan tersebut berkaitan dengan tujuan matematika yang mengharuskan siswa untuk mampu memecahkan masalah, tujuan inilah yang seharusnya dicapai oleh siswa dengan didorong oleh motivasi berprestasi. Jika siswa mengetahui tujuannya dalam matematika untuk mampu memecahkan masalah maka siswa akan terus termotivasi untuk berprestasi dan jika siswa sudah memiliki motivasi berprestasi maka siswa akan melakukan berbagai cara untuk mampu memecahkan masalah matematika dengan baik.

Identifikasi masalah penelitian ini adalah 1) siswa kurang paham akan tujuannya belajar matematika, 2) siswa kurang menyadari kebutuhannya untuk memecahkan masalah guna mencapai prestasi belajarnya, 3) siswa tidak terbiasa mengerjakan soal-soal latihan matematika yang rumit, 4) kurangnya kemampuan pemecahan masalah matematika yang dimiliki oleh siswa, 5) kurangnya dorongan pada diri siswa guna mencapai tujuan belajarnya, dan 6) siswa tidak memiliki dorongan untuk meraih prestasi dalam proses belajarnya. Identifikasi masalah tersebut dibatasi dengan pembatasan masalah yaitu pada: 1) pada kemampuan pemecahan masalah matematika, dan 2) faktor internal yaitu motivasi berprestasi. Rumusan masalah penelitian ini yaitu apakah terdapat pengaruh motivasi berprestasi terhadap kemampuan pemecahan masalah matematika siswa kelas V SD Gugus I Kuta Utara, dengan tujuan penelitian yaitu: untuk mengetahui pengaruh mtoivasi berprestasi terhadap kemampuan pemecahan masalah matematika siswa kelas V SD Gugus I Kuta Utara. Manfaat penelitian ini meliputi manfaat teoretis yakni dapat memperkaya khazanah ilmu pengetahuan khususnya dalam bidang ilmu pendidikan, serta mampu memberikan pengetahuan mengenai faktor psikologis yang dapat mempengaruhi keberhasilan anak dalam memecahkan masalah kehidupannya, dan manfaat praktis yang ditujukan kepada guru yaitu dengan hasil penelitian ini diharapkan guru mengetahui bahwa motivasi berprestasi berpengaruh terhadap kemampuan pemecahan masalah matematika siswa kelas V, sehingga guru perlu memotivasi siswa untuk berprestasi dalam proses pembelajaran matematika, bermanfaat bagi kepala sekolah yaity diharapkan kepala sekolah mampu memberikan kebijakan agar dalam setiap pembelajaran guru dapat memotivasi siswa, dan peneliti lain yaitu penelitian ini diharapkan bermanfaat sebagai kajian penelitian yang relevan bagi peneliti lain mengenai pengaruh motivasi berprestasi terhadap kemampuan pemecahan masalah matematika. Hipotesis dalam penelitian ini adalah terdapat pengaruh motivasi berprestasi terhadap kemampuan pemecahan masalah matematika siswa kelas V SD Gugus I Kuta Utara. Secara teoretis motivasi berprestasi tersebut memberikan pengaruh terhadap kemampuan pemecahan masalah matematika siswa, namun masih banyak siswa yang belum menguasai kemampuan pemecahan masalah matematika yang ad(Susanto, 2013)a. Hal ini disebabkan oleh kurangnya motivasi berprestasi siswa terhadap dirinya guna meraih kemampuannya dalam memecahkan masalah matematika dengan baik. Secara empiris berkaitan dengan hal tersebut maka akan dilakukan kajian lebih mendalam guna mengetahui pengaruh motivasi berprestasi terhadap kemampuan pemecahan masalah matematika, sehingga siswa akan memiliki motivasi berprestasi guna mampu memecahkan masalah matematika dengan baik dengan judul "Pengaruh Motivasi Berprestasi Terhadap Kemampuan Pemecahan Masalah Matematika Siswa Kelas V SD Gugus I Kuta Utara".

\section{Metode}

Pelaksanaan penelitian dilakukan di SD Gugus I Kuta Utara yang terdiri dari 7 sekolah negeri dan 3 sekolah swasata. Waktu pelaksanaan penelitian ini dilaksanakan selama 1 bulan dimulai dari bulan Maret sampai dengan bulan April 2018. Penelitian ini merupakan penelitian ex post facto dengan jenis kausal atau hubungan. Penelitian ini bertujuan untuk mengetahui apakah terdapat pengaruh motivasi berprestasi terhadap kemampuan pemecahan masalah matematika. Menurut (Sugiyono, 2015) "populasi 
adalah wilayah generalisasi yang terdiri atas obyek atau subyek yang mempunyai kualitas dan karakteristik tertentu yang ditetapkan oleh peneliti untuk dipelajari dan kemudian ditarik kesimpulan".Populasi dalam penelitian ini sebanyak 830 siswa Kelas V SD Gugus I Kuta Utara. Sampel adalah bagian dari jumlah dan karakteristik yang dipilih untuk mewakili seluruh populasi dan diambil dengan menggunakan teknik tertentu. Besaran sampel ditentukan dengan menggunakan tabel Issac and Michael dan mendapatkan besaran sebesar 243 orang. Teknik pengambilan sampel mengunakan teknik proportional random sampling atau sampel berimbang. Teknik sampling ini dilakukan untuk lebih menjamin representatif sampel dengan jumlah yang tidak sama. Teknik sampel ini dilakukan guna mengetahui tiap-tiap sampel yang akan dicari pada sebaran populasi yang ada dikelas V SD Gugus I Kuta Utara. Pengambilan sampel dilakukan dengan cara pengundian menggunakan nomor absen siswa sehingga akan diperoleh sampel yang akan digunakan pada tiap-tiap sekolah.

Pada penelitian ini menggunakan instrumen angket motivasi berprestasi dan instrumen tes kemampuan pemecahan masalah matematika. Angket motivasi berprestasi berjumlah 40 dan tes kemampuan pemecahan masalah matematika berjumlah 10 soal dengan bobot 1 sampai dengan 10 untuk setiap soal dengan penilaiannya menggunakan rubrik.Uji coba instrumen dilakukan dengan uji validitas yakni uji validitas isi dan konstruk, dan uji reliabilitas(Arikunto, 2010).

Metode analisis data dalam penelitian ini menggunakan analisis statistik inferensial. Analisis statatistik inferensial merupakan suatu cara pengolahan data yang dilakukan menggunakan rumus-rumus untuk menguji hipotesis penelitian yang akan diajukan dan kesimpulannya ditarik berdasarkan hasil pengujian terhadap hipotesis (Agung, 2016). Analisis yang digunakan untuk menguji hipotesis adalah analisis regresi linear sederhana dengan variabel bebasnya adalah motivasi berprestasi dan variabel terikatnya adalah kemampuan pemecahan masalah matematika. Menurut Nilla, Retta, \& Sari, $(2017,113)$ Regresi linear sederhana merupakan analisis yang digunakan untuk meramalkan atau memperikarakan nilai dari satu variabel dalam hubungannya dengan variabel lain yang diketahui melalui persamaan garis regresinya. (Agung, 2014) Regresi linear sederhana merupakan regresi linear yang melibatkan dua variabel (variabel $\mathrm{X}$ dan variabel Y). Analisis regresi linear sederhana ditentukan dengan persamaan

regresi yaitu $\quad \hat{Y}_{=} a+b X$. Analisis regresi linear sederhana digunakan apabila telah memenuhi uji prasyarat analisis dilakukan dengan uji normalitas dan uji lineritas. Uji normalitas merupakan uji yang digunakan untuk mengetahui residual data normal atau tidak, karena normalitas digunakan untuk menguji normalitas pada residual-nya. Uji normalitas menggunakan uji normalitas chi-kuadrat, dengan

kriteria $X^{2}{ }_{\text {hitung }}<X^{2}$ tabel pada pada taraf signifikansi 5\% maka residual data dikatakan berdistribusi normal sedangkan sebaliknya $X^{2}$ hitung $\geq X^{2}$ tabel pada taraf signifikansi $5 \%$ maka residual data dikatakan tidak berdistribusi normal. Uji linearitas menggunakan tabel analysis of varians (ANAVA) dengan kriteria jika

$F_{\text {signifikan hitung }} \geq F_{\text {signifikan tabel }}$ dengan dk pembilang 1 dan penyebut 241 maka data tersebut

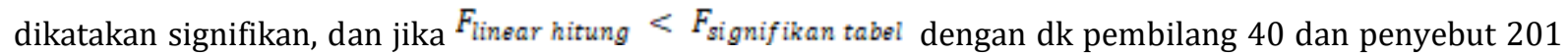
maka data tersebut linear, dan dapat dilanjutkan dengan analisis regresi linear sederhana.

Langkah-langkah yang dilakukan dalam penelitian ini dimulai dengan penelitian pendahuluan, pelaksnaan penelitian, dan penyusunan laporan berupa skripsi. Langkah-langkah tersebut dijabarkan secara lebih rinci yaitu 1) Menentukan sekolah yang akan dijadikan tempat penelitian, dan mohon izin kepada kepala sekolah untuk melakukan penelitian di sekolah tersebut, 2) melaksanakan orientasi dan observasi awal ke SD Gugus I Kuta Utara, kemudian melakukan diskusi terkait pelaksanaan penelitian dengan kepala sekolah dan guru wali kelas V, 3) membuat kisi-kisi instrumen angket dan instrumen tes, kemudian melakukan uji dengan meminta pertimbangan ahli (expert judgement), 4) menentukan sampel yang akan digunakan dari keseluruhan populasi yang ada dengan menggunakan tabel Issac and Michael, 5) menentukan sampel disetiap sekolah dengan menggunakan teknik proportional random sampling, 6) mengatur jadwal penyebaran angket, 7) melakukan uji coba instrumen penelitian di sekolah yang memiliki kriteria yang sama dengan sampel penelitian, 8) melakukan uji instrumen penelitian (uji reliabilitas), 9) melakukan penyebaran angket dan penyebaran tes uraian di sekolah-sekolah yang menjadi sampel penelitian, 10) menganalisis data hasil penelitian, dan melakukan uji hipotesis, 11) menyusun laporan berupa skripsi yang mencakup seluruh kegiatan yang dilakukan dari penelitian pendahuluan, pelaksanaan penelitian yaitu pengumpulan data dan analisis data. 


\section{Hasil dan Pembahasan}

Data motivasi berprestasi diperoleh melalui penyebaran angket motivasi berprestasi dan data kemampuan pemecahan masalah matematika diperoleh melalui tes kemampuan pemecahan masalah matematika berupa soal cerita matematika yang diberikan kepada siswa kelas V SD Gugus I Kuta Utara yang dijadikan sampel penelitian. Data akhir yang telah diperoleh melalui angket dan tes kemampuan pemecahan masalah matematika maka akan digunakan untuk menganalisis hipotesis. Hipotesis diuji dengan menggunakan uji regresi linear sederhana. Sebelum melakukan uji analisis regresi linear sederhana maka dilakukan uji normalitas dan uji lineritas sebagai uji prasyarat analisis. Uji normalitas dilakukan dengan mencari nilai residual dari data dan kemudian dilakukan uji normalitas menggunakan uji normalitas chi-kuadrat. $X^{2}=\sum \frac{\left(f_{0}-f_{x}\right)}{f_{x}}$ Setelah dilakukan uji normalitas tersebut maka didapatkan $X^{2}{ }_{\text {hitung }}=14,984$ dan $X^{2}$ tabel $=15,507$. Uji normalitas tersebut telah memenuhi kriteria yaitu $X^{2}{ }_{\text {hitung }}=$ $14,984<X^{2}{ }_{\text {tabel }}=15,507$ pada taraf signifikansi $5 \%$ dan dengan $\mathrm{db}=10-2=8$, maka residual data dikatakan berdistribusi normal. Selanjutnya dilakukan uji prasyarat yang kedua yaitu uji linearitas dengan menggunakan tabel analysis of varians (ANAVA) dengan tabel ANAVA akan diketahui secara langsung nilai signifikan dan nilai linear dari sebuah data tersebut. berikut adalah rekapitulasi hasil uji signifikan dan uji linearitas dengan tabel ANAVA. Pada tabel tersebut diketahui bahwa hasil yang ditunjukkan oleh tabel

ANAVA mendapatkan $F_{\text {signifikan hitung }}=34,42$ dan dibandingkan dengan $F_{\text {signifikan tabel }}$ yang memenuhi kriteria $F_{\text {signifikan hitung }} \geq F_{\text {signifikan tabel }}$ dengan dk pembilang 1 dan penyebut 241 maka data tersebut signifikan. Sedangkan hasil pada tabel yang menunjukkan angka 0,81 dengan kriteria jika

$F_{\text {linear hitung }}<F_{\text {signifikan tabel }}$ dengan dk pembilang 40 dan penyebut 201 maka data tersebut linear.

Dengan demikian, dikarenakan uji prasyarat analisis regresi telah terpenuhi yakni normal dan linear maka dapat dilanjutkan dengan uji hipotesis menggunakan analisis regresi linear sederhana. Analisis regresi linear sederhana bertujuan untuk memprediksi atau memperkirakan nilai hubungan variabel satu dengan variabel yang lainnya menggunakan sebuah analisis yang diketahui melalui persamaan garis regresinya. Analisis regresi linear sederhana dalam penelitian ini menggunakan

persaamaan yaitu $\hat{Y}_{=} a+b X$, dengan nilai a sebagai konstanta, nilai b sebagai koifisien regresi dan nilai X sebagai predictor. Dengan persamaan tersebut maka sebelumnya harus diketahui nilai a dan b dengan rumus :

$$
\begin{aligned}
& a=\frac{(\Sigma Y)\left(\Sigma X^{2}\right)-(\Sigma X)(\Sigma X Y)}{n \Sigma X^{2}-(\Sigma X)^{2}} \\
& b=\frac{n \Sigma X Y-(\Sigma X)(\Sigma Y)}{n \Sigma X^{2}-(\Sigma X)^{2}}
\end{aligned}
$$

setelah diketahui nilai a dan $b$, maka nilai tersebut dimasukkan kedalam rumus persamaan regresi. Dengan demikian maka didapat persamaan regresinya adalah sebagai berikut :

$$
\begin{aligned}
& =a+b X \\
& \hat{Y}_{=} 20,84+0,41 X \\
& \hat{Y}_{=} 20,84+0,41(50) \\
& \hat{Y}_{=} 41,34
\end{aligned}
$$

Dari persamaan regresi dan garis regresi tersebut dapat diartikan bahwa setiap penambahan 1 nilai motivasi berprestasi, maka nilai kemampuan pemecahan masalah matematika bertambah sebesar 0,41 selain itu dengan hasil yang telah didapatkan maka dapat dikatakan bahwa terdapat pengaruh motivasi berprestasi terhadap kemampuan pemecahan masalah matematika. Bahwa semakin tinggi nilai motivasi berprestasi pada diri siswa maka akan memberikan pengaruh semakin baik terhadap kemampuan pemecahan masalah matematika siswa kelas V SD Gugus I Kuta Utara. Begitu pula sebaliknya semakin 
rendah nilai motivasi berprestasi maka semakin kurang kemampuan pemecahan masalah matematika siswa kelas V SD Gugus I Kuta Utara. Hal ini disebabkan oleh kurangnya dorongan dalam diri siswa untuk mampu memecahkan masalah matematika. Dorongan ini harus ditimbulkan pada diri siswa agar semakin tinggi nilainya, karena dengan hal tersebut siswa dapat memberikan hasil yang positif dalam belajarnya terutama kemampuan pemecahan masalah matematika. Sedangkan untuk mengetahui seberapa besar hubungan antara motivasi berprestasi terhadap kemampuan pemecahan masalah didapat hasil yaitu 0,354 besarnya koifisien korelasi antara motivasi berprestasi terhadap kemampuan pemecahan masalah matematika yang berarti hubungan tersebut cukup signifikan, bahwa semakin baik motivasi berprestasi maka akan memberikan pengaruh yang lebih baik terhadap kemampuan pemecahan masalah matematika. Berdasarkan hasil koifisien korelasi tersebut maka memberikan arti hubungan motivasi berprestasi terhadap kemampuan pemecahan masalah matematika cukup tinggi, dengan koifisien determinasi $=$ 0,125 sehingga didapat bahwa kemampuan pemecahan masalah matematika dipengaruhi oleh motivasi berprestasi sebesar $12,5 \%$ dan masih terdapat faktor lain yang mempengaruhi kemampuan pemecahan masalah matematika.

\section{Simpulan dan Saran}

Berdasarkan hasil penelitian yang telah dipaparkan maka dapat disimpulkan bahwa koefisien korelasi sebesar 0,354 dan koefisien determinasi sebesar 0,125 atau 12,5\% sehingga hipotesis nol 0 yang menyatakan tidak terdapat pengaruh motivasi berprestasi terhadap kemampuan pemecahan masalah matematika ditolak. Hal ini menunjukkan bahwa $\mathrm{H}_{a}$ diterima yang menyatakan terdapat pengaruh motivasi berprestasi terhadap kemampuan pemecahan masalah matematika siswa kelas V SD Gugus I Kuta Utara. Saran yang dapat disampaikan berdasarkan proses dan hasil penelitian yang telah dilakukan adalah sebagai berikut: (1) kepada guru, dalam melaksanakan proses pembelajaran, guru dapat menggunakan meningkatkan motivasi siswa sehingga kemampuan dalam memecahkan masalah matematika menjadi meningkat. (2) kepada kepala sekolah, hendaknya kepala sekolah memfasilitasi guru dalam meningkatkan motivasi belajar siswa sehingga pembelajaran menjadi lebih bermakna (3) kepada peneliti lain, peneliti lain dapat menjadikan penelitian ini sebagai referensi terkait penelitian sejenis.

\section{Daftar Rujukan}

Agung, A. A. G. (2014). Metodologi Penelitian Pendidikan. Malang: Aditya Media Publish.

Agung, A. A. G. (2016). Metodologi Penelitian. Singaraja: Undiksha.

Arikunto, S. (2010). Prosedur Penelitian Suatu Pendekatan Praktik. Jakarta: PT Rineka Cipta.

Djaali. (2012). Psikologi Pendidikan. Jakarta: Bumi Aksara.

Emda, A. (2017). Kedudukan Motivasi Belajar Siswa Dalam Pembelajaran. Lantanida Journal, 5(2).

Hadianti, L. S. (2018). Pengaruh Pelaksanaan Tata Tertib Sekolah Terhadap Kedisiplinan Belajar Siswa. Jurnal Pendidikan Universitas Garut, 2(1), 1-8.

Nilla, K., Retta, A. M., \& Sari, N. (2017). Pengantar Statistika Penelitian. Depok: PT Raja Grafindo Persada.

Riffyanti, L. (2017). Analisis Strategi Langkah Mundur dan Bernalar Logis dalam Menentukan Bilangan dan Nilai. Jurnal Pendidikan Matematika FKIP Univ. Muhammadiyah Metro, 6(1).

Roebyanto, G., \& Harmini, S. (2017). Pemecahan Masalah Matematika untuk PGSD. Bandung: Remaja Rosdakarya.

Slameto. (2010). Belajar dan Faktor-Faktor yang Mempengaruhi. Jakarta: Ranika Cipta.

Sugiyono. (2015). Metode Penelitian Pendidikan Pendekatan Kuantitatif,Kualitatif, dan R\&D. Bandung: Alfabeta.

Susanto, A. (2013). Teori Belajar dan Pembelajaran di Sekolah Dasar. Jakarta: Prenamedia Group.

Trianto. (2010). Model Pembelajaran Terpadu Konsep, Strategi, dan Implementasinya dalam KTSP. Jakarta: Kencana Prenada Media Group. 